\title{
Notes on the vocalizations of Long-billed Wren (Thryothorus longirostris)
}

Peter Boesman

In the following we briefly analyze and compare voice of the two races of Long-billed Wren (Thryothorus longirostris). We also try to quantify the extent of any vocal differences using the criteria proposed by Tobias et al. (2010), as a support for taxonomic review. We have made use of sound recordings available on-line from Xeno Canto (XC).

Just like some other members of this genus, T. longiostris has a 'short song' consisting of a short phrase of one or a few notes repeated at intervals, and a synchronous duet song in which both members of a pair sing continuously over a longer period. The latter is heard much less than the 'short song'.

An overview of vocalizations per race, illustrated with sonograms:

\section{bahiae}

Short song
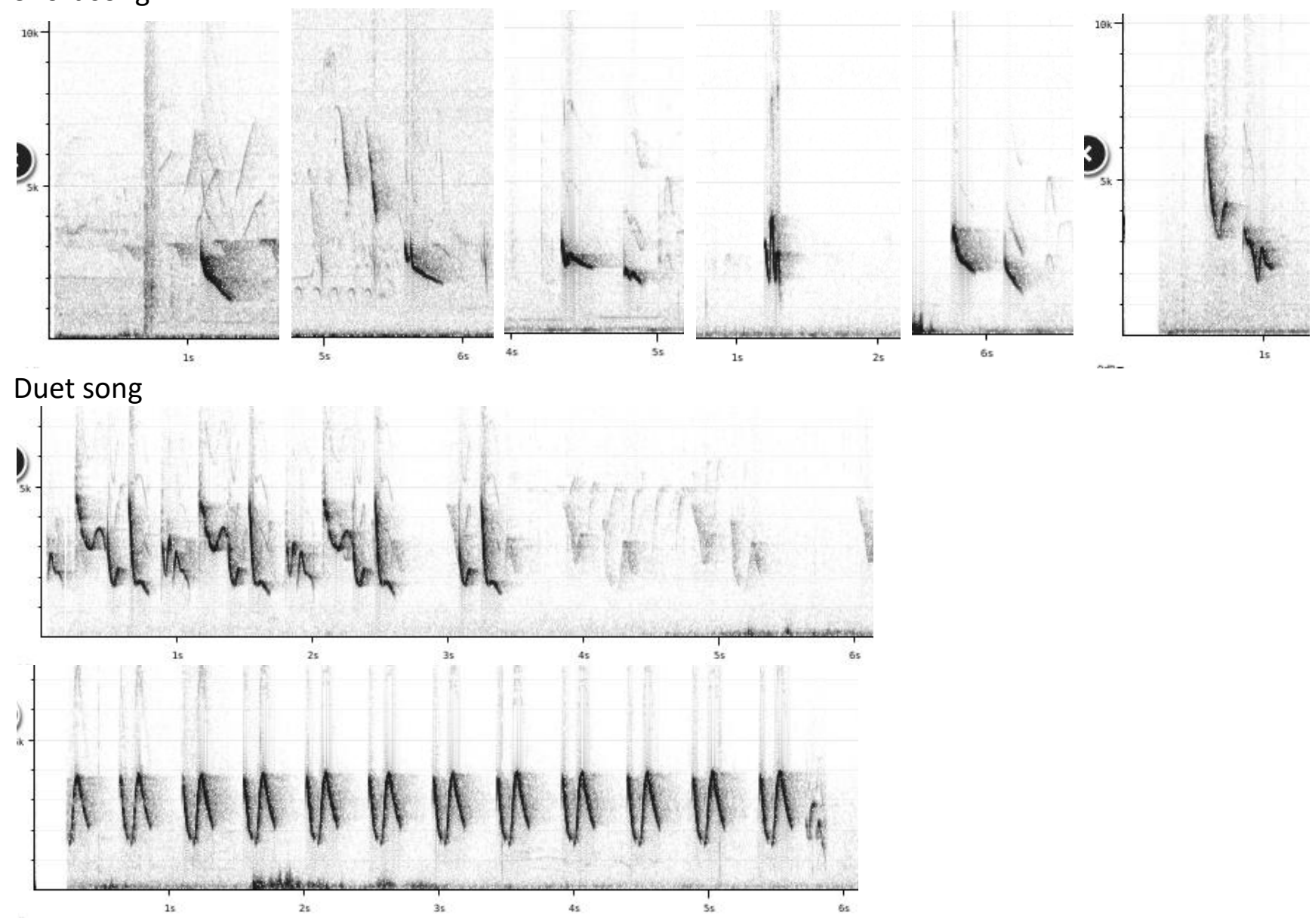

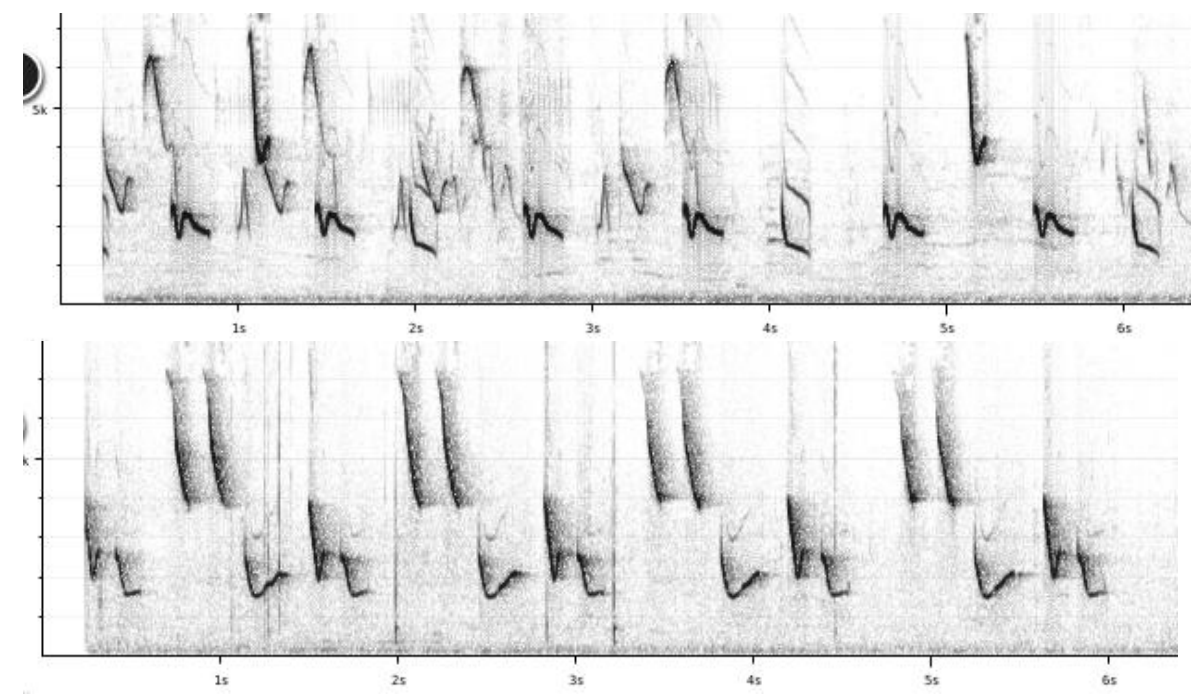

\section{longirostris}

Short song

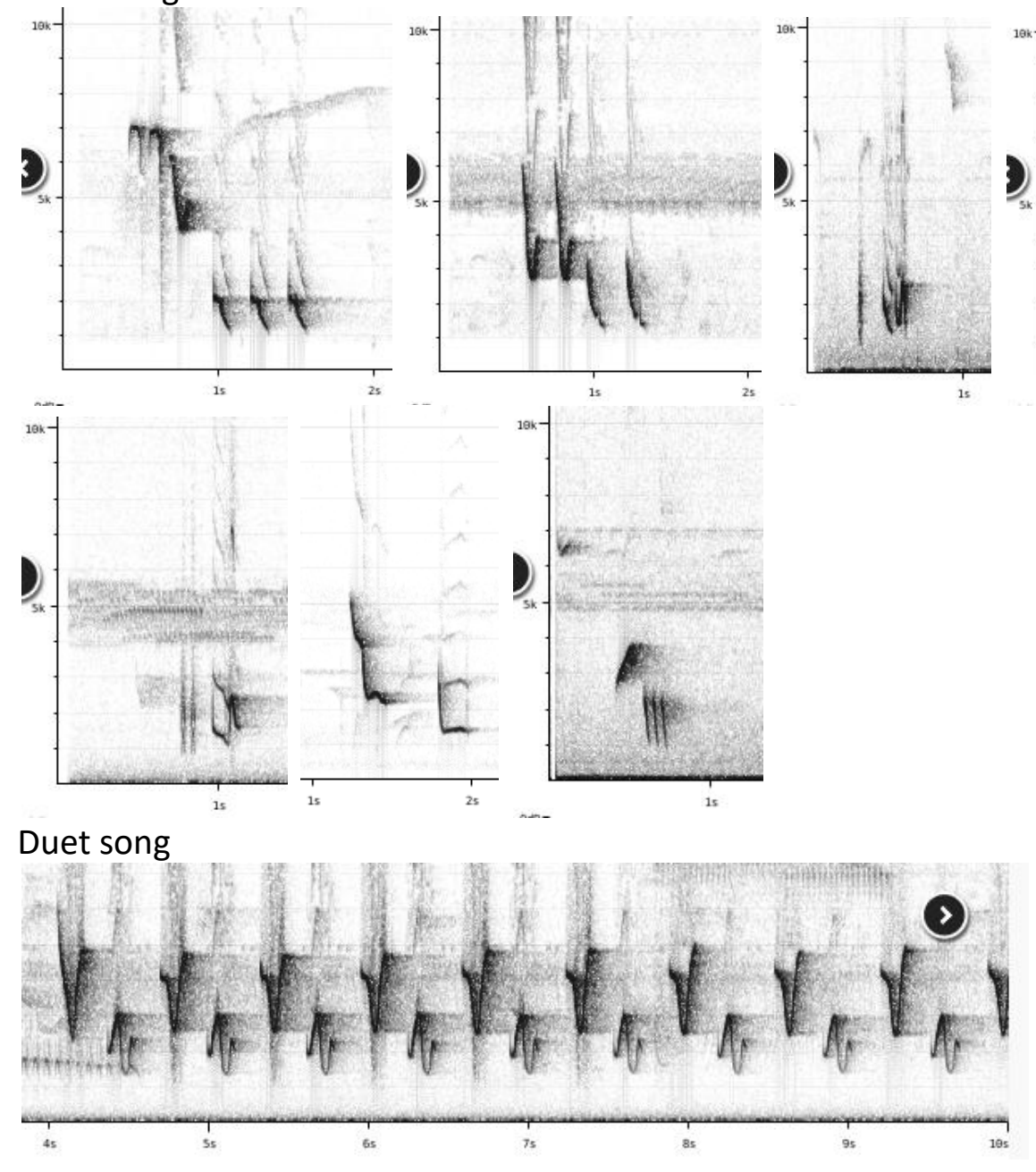




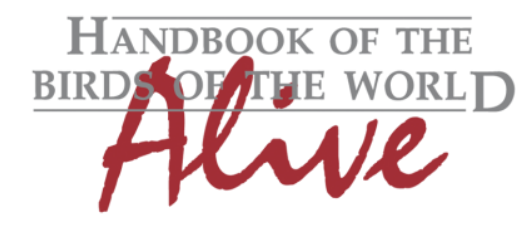

\section{ORNITHOLOGICAL NOTES}
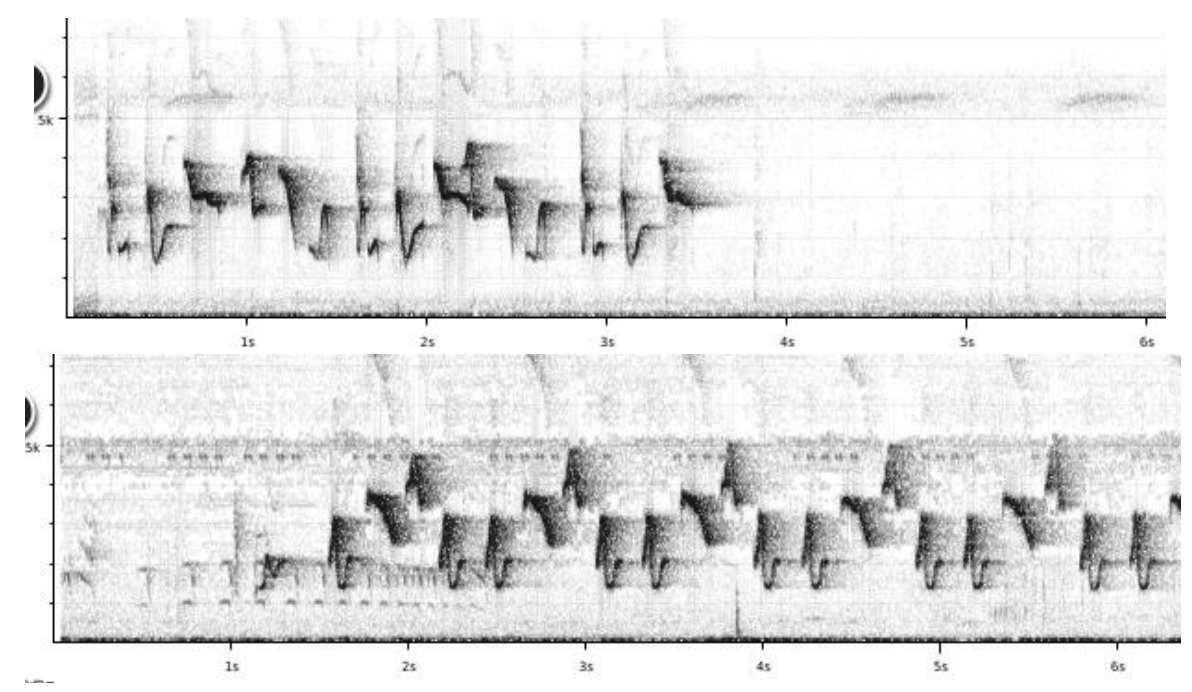

Both races show quite some variability in song.

Short song of bahiae on average consists of simpler notes, typically 1-3 notes vs 2-6 notes in longirostris.

Duet song of both races is quite similar, with basic sound parameters about the same: phrases consist of 2-6 notes, with phrase length quite variable, frequency range is similar, with especially in bahiae a very wide range. A larger set of recordings would be needed to prove consistent differences, if any. All in all, vocal differences between the two races seem to be quite minor.

Based on a slight difference in short song (average number of notes) a vocal score of 1-2 could be given.

This note was finalized on 15th April 2016, using sound recordings available on-line at that moment. We would like to thank in particular the many sound recordists who placed their recordings for this species on XC.

\section{References}

Tobias, J.A., Seddon, N., Spottiswoode, C.N., Pilgrim, J.D., Fishpool, L.D.C. \& Collar, N.J. (2010). Quantitative criteria for species delimitation. Ibis 152(4): 724-746.

\section{Recommended citation}

Boesman, P. (2016). Notes on the vocalizations of Long-billed Wren (Thryothorus longirostris). HBW Alive Ornithological Note 292. In: Handbook of the Birds of the World Alive. Lynx Edicions, Barcelona. (retrieved from http://www.hbw.com/node/1251740 on 12 October 2016). 